Research Article for bioRxiv

\title{
Efficacy of the MEK1/2 inhibitor trametinib in combination with clinically-investigated $\gamma$ - secretase inhibitors in rhabdomyosarcoma
}

running title:

MEK1/2 with $\gamma$-secretase inhibitors in rhabdomyosarcoma

Megan M. Cleary ${ }^{1}$, Douglas S. Hawkins ${ }^{2}$, Charles Keller ${ }^{1 *}$

${ }^{1}$ Children's Cancer Therapy Development Institute, Beaverton, OR 97005 USA

${ }^{2}$ Seattle Children's Hostpital, Seattle, WA 98105 USA

* correspondence: Charles Keller, 12655 Sw Beaverdam Rd W, Beaverton OR 97005 USA, tel: 801-232-8038, fax: 270-675-3313, email: charles@,cc-tdi.org

word count (998 words in main text, excluding Abstract, Methods, References and Figure legends)

Competing Interests Statement: CK collaborates with Novartis in no-cost studies, and Novartis is the marketer of trametinib. 


\begin{abstract}
The childhood muscle cancer rhabdomyosarcoma (RMS) is the most common pediatric soft tissue sarcoma. In the last 40 years, outcomes for low and intermediate risk patients have improved; however, high risk patients with metastatic disease still have poor overall survival. Differentiation therapy for RMS has been considered a potential clinical approach to halting tumor progression by inducing the terminal myogenic differentiation program, and thus reducing the need for cytotoxic chemotherapy. Both the NOTCH and MEK pathway have been shown to play varying roles in inducing differentiation in RMS cells. Here, we tested several different RMS cell lines harboring varying genetic abnormalities with the MEK inhibitor trametinib alone, and in combination with $\gamma$-secretase inhibitors and found no significant effect on cell viability when used together.
\end{abstract}




\section{Introduction}

Rhabdomyosarcoma (RMS) is a rare pediatric cancer thought to phenocopy a skeletal muscle lineage. RMS presents as one of two main subtypes, each exhibiting a unique histological and molecular profile. Embryonal rhabdomyosarcoma (eRMS) is characterized by widespread genetic instability with $P 53, R A S, P I K 3 C A, R B 1$ and FGFR4 disruptions often observed (1-6). Alveolar rhabdomyosarcoma (aRMS) is defined by a $\mathrm{t}(2 ; 13)$ or $\mathrm{t}(1 ; 13)$ chromosomal translocation that results in the DNA binding domain of either PAX7 or PAX3 fusing with the transactivation domain of FOXO1, creating an oncogenic transcription factor $(7,8)$. Even though RMS is the most common soft tissue sarcoma in children, survival for patients with metastasis has remained unchanged over the past 47 years despite intensive multimodal therapy.

Histologically, rhabdomyosarcoma expresses markers of myogenic differentiation such as myogenin and MyoD1 $(9,10)$; however, the function of these myogenic proteins is often impaired and RMS cells fail to fully differentiate (11). RMS is believed to circumvent terminal differentiation, allowing RMS tumor cells to divide uncontrollably. Restoring the terminal differentiation program is posited to slow or halt tumor growth by transforming malignant, proliferating cells into non-dividing cells. Differentiation therapy appears to have clinical potential, as eRMS cells have been observed to differentiate following chemotherapy and radiation (12-14), although this response is not often found in aRMS.

Different groups have uncovered strategies for inducing differentiation in RMS and thus slowing growth, but with limited success. Genetic suppression of the Notch1-Heyl pathway by shRNA in eRMS RD cells, or suppression of Notch-3 by siRNA in RD and aRMS Rh30 cells results in an increase of myogenic differentiation markers in vitro, and pharmacological inhibition of Notch signaling using a $\gamma$-secretase inhibitor reduces cell proliferation $(15,16)$. In RD cells, modulating miR-206 increases differentiation by $30 \%$ in vitro (17), while GSK3 inhibitors significantly 
increase the number of myosin heavy chain positive cells after treatment for 72 hours (18). The inhibition of RAF/MEK protein kinases induce terminal differentiation in RD cells (18), a result not surprising given that RAS pathway activation is common in eRMS, and that this disease demonstrates a "Ras on" gene signature $(5,19)$. In vivo trametinib slows but does not halt tumor growth in eRMS cell lines SMS-CTR and BIRCH, but not RD; these tumors exhibit an increase in nuclear MYOG expression, but not across all cells of a tumor, and complete terminal differentiation is not observed (20). Taken together, these results demonstrate the difficulty in achieving complete terminal differentiation and suggest the therapeutic benefit of a single agent differentiation therapy will have limited clinical success, and thus combining pathway inhibitors will likely be necessary to achieve tumor remission.

Unpublished data from our lab suggests in vitro synergy when simultaneously targeting the MAPK and Notch pathways in RMS cells. Presented here are the in vitro drug screening assays performed on a range of aRMS and eRMS cells lines and primary patient cells harboring different genetic hallmarks, to examine the efficacy of the MEK inhibitor trametinib alone or in combination with Notch signaling inhibition using $\gamma$-secretase inhibitors. 


\section{Results}

\section{Trametinib decreases viability in a range of cell lines}

Our experiments confirmed that treatment of KRAS-driven RD cells with sub-micromolar concentrations $(684 \mathrm{nM})$ of trametinib for 72 hours resulted in cytotoxicity (Figure 1A). Unexpectedly, SCA1-01, a Kras activated primary mouse tumor cell line, was not sensitive to MEK inhibition (IC50=38,000 $\mathrm{nM}$ ), indicating that a pathway other than RAS-MEK is necessary for tumor cell maintenance (Figure 3). An aRMS patient-derived primary tumor cell culture (CF1, Figure 2A) and an aRMS cell line (Rh30, Figure 4A) that both harbored the PAX3:FOXO1 chromosomal translocation were also treated with trametinib and responded with low micromolar concentrations (IC50=1,557 nM and $803 \mathrm{nM}$, respectively). Finally, we tested CW9019, a cell line that has an alveolar histology and harbored a $\mathrm{t}(1 ; 13)$ reciprocal translocation resulting in a PAX7:FOXO1 fusion protein. This cell line was the most sensitive to trametinib treatment, with a half maximal inhibitory concentration of $113 \mathrm{nM}$ (Figure 5A). However, the in vitro IC50 values for these cell lines are still well above the clinically achievable dose of trametinib (36 nM) (21).

\section{Trametinib in combination with $\gamma$-secretase inhibitors does not exhibit synergistic cytotoxicity}

To query whether trametinib augmented with inhibition of the Notch pathway would cause additive or synergistic cytotoxicity, we additionally tested the above cell lines in combination with one of the clinical $\gamma$-secretase inhibitors, nirogacestat, semagacestat or RO4929097. $\gamma$-secretase inhibitors were combined with either a low, clinically achievable dose $(50 \mathrm{nM})$ or a high dose (150 $\mathrm{nM}$ ) of trametinib. Little or no synergy was observed at clinically achievable concentrations of $\gamma$ secretase inhibitors in all cell lines tested. In RD cells $\gamma$-secretase treatment alone did not cause cytotoxicity (Figure 1B-D); synergy was only observed at the highest concentrations of 
nirogacestat and the highest tested concentration of trametinib $(150 \mathrm{nM}$, Figure 1F), but not with RO4929097 and a low concentration of trametinib (50nM, Figure 1E). $\gamma$-secretase inhibitors exhibited no synergistic effect on the aRMS primary patient sample cell culture CF-1 (22), the aRMS cell line Rh30 or the mouse non-myogenic sarcoma tumor SCA-1 when combined with trametinib (Figure 2, 3, 4 E-F). The aRMS cell line CW9019 which was most sensitive to single agent trametinib treatment exhibited some single agent sensitivity to the highest concentrations of nirogacestat (Figure 5C) but not semagacestat or RO4929097 (Figure 5 B,D). Combination treatment with $150 \mathrm{nM}$ trametinib and $\gamma$-secretase inhibitors did not demonstrate any synergistic decrease in cell viability (Figure 5 E-F). 


\section{Discussion}

A common assumption in clinical trial design is that single agents should have strong activity in phase I/II studies to advance to phase III trials. However, some drugs may have substantial synergy and might improve survival by $10-20 \%$ in Phase III clinical trials, even if no activity could be seen in phase I/II trials. In this context, we sought to test the combination of two drugs with limited single agent potential, MEK inhibitors and $\gamma$-secretase inhibitors. Unfortunately, even in the earliest in vitro pre-clinical studies, no supporting evidence for this combination approach could be garnered. 


\section{Materials and methods}

\section{Cell lines}

SCA1-01 cells were donated by Dr. Amy Wagers and Dr. Simone Hettmer (Harvard University) and established from a Kras;p16p19 ${ }^{\text {null }}$ mouse non-myogenic sarcoma tumor. CW9019 cells were a generous gift from Dr. Fred Barr (National Cancer Institute). SCA-1 and CW9019 were maintained in DMEM supplemented with 10\% FBS and 1\% penicillin-streptomycin and maintained at $37^{\circ}$. RD (CCL-136) eRMS and Rh30 (CRL-2061) aRMS cells were purchased from ATCC (Manassas, VA) and cultured per manufacturer's instructions. CF-1 is a primary patient sample isolated from a 18 month old male presenting with alveolar rhabdomyosarcoma (22). These cells were cultured in RPMI supplemented with 10\% FBS and 1\% penicillin-streptomycin and maintained at $37^{\circ}$. CF-1 cells are only tested at passage earlier than 8 . All human cell lines were authenticated using short tandem repeat analysis performed by the University of Arizona Genetics Core (Tuscon, AZ).

\section{In Vitro inhibitor testing}

Small molecule inhibitors semagacestat (LY-450139, S1594), nirogacestat (PF03084014, S1575) and RO4929097 (S8018) were purchased from Selleckchem (Houston, TX), reconstituted to manufacturers specifications and stored in $-80^{\circ} \mathrm{C}$. To generate a standard 10 -point dose response curve, inhibitors were distributed as single agents into 96 well plates to produce final concentrations ranging from $100 \mu \mathrm{M}$ to $0.005 \mu \mathrm{M}$. Combination plates were likewise prepared in 96 well plates with trametinib (GSK1120212, S2673) at fixed final concentrations of 50nM or 150nM, paired with $\gamma$-secretase inhibitors at varying concentration identical to those used for single agents. All drug plates were stored at $-20^{\circ} \mathrm{C}$ and thawed a maximum of 3 times. Cells were seeded at a density of $3 \times 10^{4}$ cells per well in a 96 well plate on day $0(0 \mathrm{~h})$. On day $1(24 \mathrm{~h})$ each drug or 
combination was added to the cells for a final volume of $100 \mu \mathrm{L}$ per well. Cells were incubated at $37^{\circ}$ with $5 \% \mathrm{CO}_{2}$ for 72 hours. On day 4 (96h) compounds were screened for their effect on proliferation by adding $100 \mu \mathrm{L}$ room temperature cell titer-glo (CTG, Promega, Madison, WI) to each well and rocking in the dark at room temperature for 10 minutes. Luminescence was measured with a Biotek Synergy plate reader. Standard dose response curves and IC50 values were calculated with GraphPad Prism software using log-10 transformed concentrations and normalized values. Each dose was performed in triplicate and all experiments were repeated three times. 


\section{References}

1. Taylor AC, Shu L, Danks MK, Poquette CA, Shetty S, Thayer MJ, et al. p53 mutation and MDM2 amplification frequency in pediatric rhabdomyosarcoma tumors and cell lines. Med Pediatr Oncol. 2000 Aug 1;35(2):96-103.

2. Stratton MR, Fisher C, Gusterson BA, Cooper CS. Detection of Point Mutations in N-ras and Kras Genes of Human Embryonal Rhabdomyosarcomas Using Oligonucleotide Probes and the Polymerase Chain Reaction1. Cancer Res. 1989;49(22):6324-7.

3. Kohashi K, Oda Y, Yamamoto H, Tamiya S, Takahira T, Takahashi Y, et al. Alterations of RB1 gene in embryonal and alveolar rhabdomyosarcoma: special reference to utility of $\mathrm{pRB}$ immunoreactivity in differential diagnosis of rhabdomyosarcoma subtype. J Cancer Res Clin Oncol. 2008 Oct 2;134(10):1097-103.

4. Taylor JG, Cheuk AT, Tsang PS, Chung J-Y, Song YK, Desai K, et al. Identification of FGFR4activating mutations in human rhabdomyosarcomas that promote metastasis in xenotransplanted models. J Clin Invest. 2009 Nov 2;119(11):3395-407.

5. Shern JF, Chen L, Chmielecki J, Wei JS, Patidar R, Rosenberg M, et al. Comprehensive genomic analysis of rhabdomyosarcoma reveals a landscape of alterations affecting a common genetic axis in fusion-positive and fusion-negative tumors. Cancer Discov. 2014 Feb;4(2):216-31.

6. Shukla N, Ameur N, Yilmaz I, Nafa K, Lau C-Y, Marchetti A, et al. Oncogene Mutation Profiling of Pediatric Solid Tumors Reveals Significant Subsets of Embryonal Rhabdomyosarcoma and Neuroblastoma with Mutated Genes in Growth Signaling Pathways. Clin Cancer Res. 2012;18(3):748-57.

7. Arden KC, Anderson MJ, Finckenstein FG, Czekay S, Cavenee WK. Detection of the t(2;13) chromosomal translocation in alveolar rhabdomyosarcoma using the reverse transcriptasepolymerase chain reaction. Genes, Chromosom Cancer. 1996 Aug;16(4):254-60. 
8. Barr FG, Galili N, Holick J, Biegel JA, Rovera G, Emanuel BS. Rearrangement of the PAX3 paired box gene in the paediatric solid tumour alveolar rhabdomyosarcoma. Nat Genet. 1993 Feb;3(2):113-7.

9. Wang NP, Marx J, Mcnutt MA, Rutledge JC, Gown AM. Expression of Myogenic Regulatory Proteins (Myogenin and MyoDi) in Small Blue Round Cell Tumors of Childhood. Am J Pathol. 1995;147(6):1799-810.

10. Sebire NJ, Malone M. Myogenin and MyoD1 expression in paediatric rhabdomyosarcomas. J Clin Pathol. 2003 Jun;56(6):412-6.

11. Keller C, Guttridge DC. Mechanisms of impaired differentiation in rhabdomyosarcoma. FEBS J. 2013;280(17):4323-34.

12. Smith LM, Anderson JR, Coffin CM. Cytodifferentiation and clinical outcome after chemotherapy and radiation therapy for rhabdomyosarcoma (RMS). Med Pediatr Oncol. 2002 Jun 1;38(6):398404.

13. Coffin CM, Rulon J, Smith L, Bruggers C, White F V. Pathologic features of rhabdomyosarcoma before and after treatment: a clinicopathologic and immunohistochemical analysis. Mod Pathol. 1997 Dec;10(12):1175-87.

14. Svalina MN, Keller C. YAPping about differentiation therapy in muscle cancer. Cancer Cell. 2014 Aug 11;26(2):154-5.

15. Belyea B, Naini S, Bentley RC, Linardic CM. Inhibition of the Notch-Hey1 Axis Blocks Embryonal Rhabdomyosarcoma Tumorigenesis. Clin Cancer Res. 2011;17(23):7324-36.

16. Raimondi L, Ciarapica R, De Salvo M, Verginelli F, Gueguen M, Martini C, et al. Inhibition of Notch3 signalling induces rhabdomyosarcoma cell differentiation promoting p38 phosphorylation and p21(Cip1) expression and hampers tumour cell growth in vitro and in vivo. Cell Death Differ. 2012 May;19(5):871-81. 
17. Wegorzewska M, Krauss RS, Kang J-S. Overexpression of the immunoglobulin superfamily members CDO and BOC enhances differentiation of the human rhabdomyosarcoma cell line RD. Mol Carcinog. 2003 May 1;37(1):1-4.

18. Chen EY, Deran MT, Ignatius MS, Grandinetti KB, Clagg R, Mccarthy KM, et al. Glycogen synthase kinase 3 inhibitors induce the canonical WNT/ $\beta$-catenin pathway to suppress growth and self-renewal in embryonal rhabdomyosarcoma. PNAS. 2014;111(14):5349-54.

19. Rubin BP, Nishijo K, Chen H-IH, Yi X, Schuetze DP, Pal R, et al. Evidence for an unanticipated relationship between undifferentiated pleomorphic sarcoma and embryonal rhabdomyosarcoma. Cancer Cell. 2011 Feb 15;19(2):177-91.

20. Yohe ME, Gryder BE, Shern JF, Song YK, Chou HC, Sindiri S, et al. MEK inhibition induces MYOG and remodels super-enhancers in RAS-driven rhabdomyosarcoma. Sci Transl Med. $2018 ; 10(448)$.

21. Crawford K, Cleary MM, Ricker CA, Svalina MN, Shern JF, Khan J, et al. MEK1/2 in Rhabdomyosarcoma. Prog. 2019;

22. Bharathy N, Berlow NE, Wang E, Abraham J, Settelmeyer TP, Hooper JE, et al. The HDAC3SMARCA4-miR-27a axis promotes expression of the PAX3:FOXO1 fusion oncogene in rhabdomyosarcoma. Sci Signal. 2018 Nov 20;11(557). 


\section{Acknowledgements}

This work was supported in part by NCI R01 grant R01CA189299 as well as The Building Blocks Project.

We thank Dr. Amy Wagers and Dr. Simone Hettmer for donations of cell lines and Dr. Srinath Sampath and Dr. Sihari Sampath helpful discussions and advice.

\section{Competing Interests Statement}

CK collaborates with Novartis in no-cost studies, and Novartis is the marketer of trametinib.

\section{Compliance with ethical standards}

No human subjects or animals were used in these studies. 


\section{Additional Information}

\section{Data Deposition and Access}

No genomic data sets apply to this study

\section{$\underline{\text { Author Contributions }}$}

MMC, CK, DSH participated in study design. MMC performed experiments. MMC, CK participated in data analysis. MMC, CK participated in writing manuscript. 


\section{Figure Legends}

Fig 1. Cell viability assays using the KRAS-driven human eRMS cell line RD. Cells were treated with trametinib (A) or $\gamma$-secretase inhibitors (B-D) alone, or $50 \mathrm{nM}$ (IC62) trametinib (E) or $150 \mathrm{nM}$ (IC57) trametinib $(\mathrm{F})$ in combination with varying concentration of $\gamma$-secretase inhibitors.

Fig 2. Cell viability assays using the primary patient derived aRMS cell culture CF-1. Cells were treated with trametinib (A) or $\gamma$-secretase inhibitors alone (B-D), or $150 \mathrm{nM}$ (IC78) trametinib in combination with varying concentration of $\gamma$-secretase inhibitors (E-G).

Fig 3. Cell viability assays using the KRAS;p16p19null $(C d k n 2 a)$ mouse non-myogenic soft tissue sarcoma tumor SCA-1. Cells were treated with trametinib (A) or $\gamma$-secretase inhibitors alone (B-D), or $150 \mathrm{nM}$ (IC93) trametinib in combination with varying concentration of $\gamma$-secretase inhibitors (E-G).

Fig 4. Cell viability assays using the human aRMS cell line Rh30. Cells were treated with trametinib (A) or $\gamma$-secretase inhibitors alone (B-D), or 150nM (IC64) trametinib (F) or $50 \mathrm{nM}$ (IC73) trametinib (E) in combination with varying concentration of $\gamma$-secretase inhibitors.

Fig 5. Cell viability assays using the human aRMS cell line CW9019. Cells were treated with trametinib (A) or $\gamma$-secretase inhibitors alone (B-D), or 150nM (IC64) trametinib in combination with varying concentration of $\gamma$-secretase inhibitors (E-G). 
bioRxiv preprint doi: https://doi org/101101/622522; this version posted April 29, 2019. The copyright holder for this preprint (which was not certified by peer review) is the author/funder, who has granted bioRxiv a license to display the preprint in perpetuity. It is made available under aCC-BY-NC-ND 4.0 International license.

Figure 1
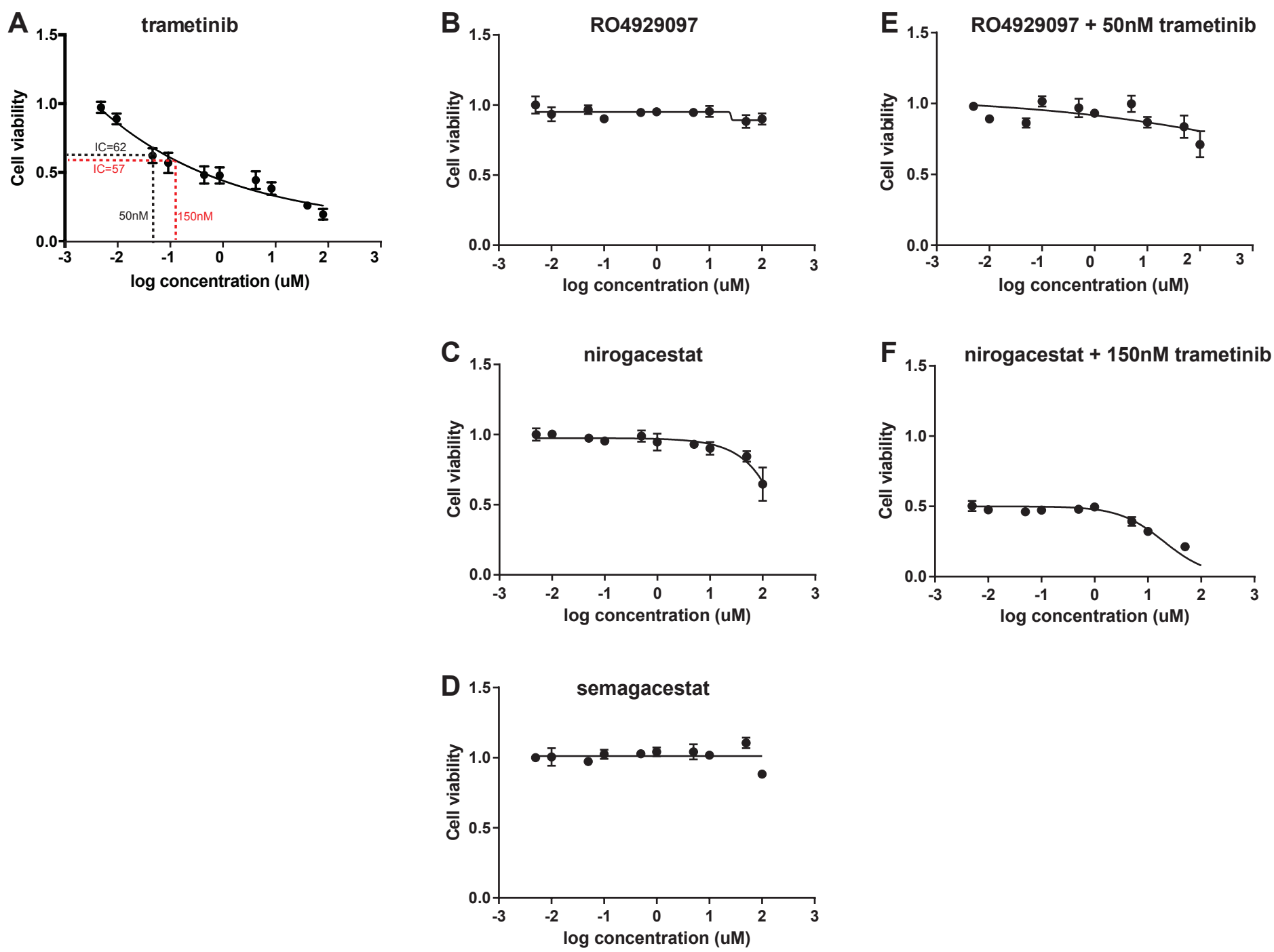
bioRxiv preprint doi: https://doi org/10.1101/622522; this version posted April 29,2019 . The copyright holder for this preprint (which was not certified by peer review) is the author/funder, who has granted bioRxiv a license to display the preprint in perpetuity. It is made available under aCC-BY-NC-ND 4.0 International license.

Figure 2

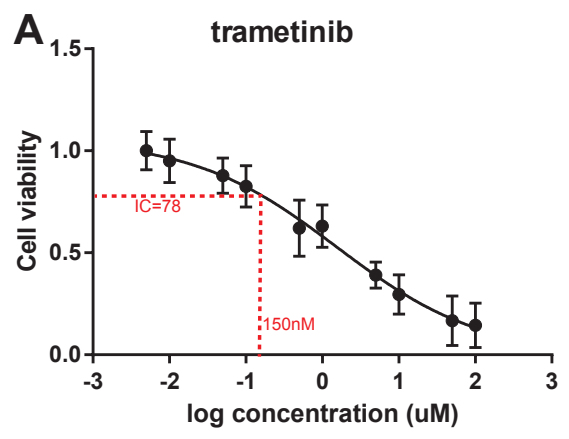

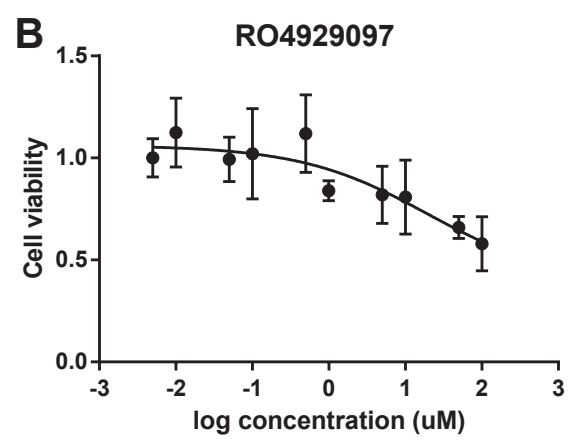
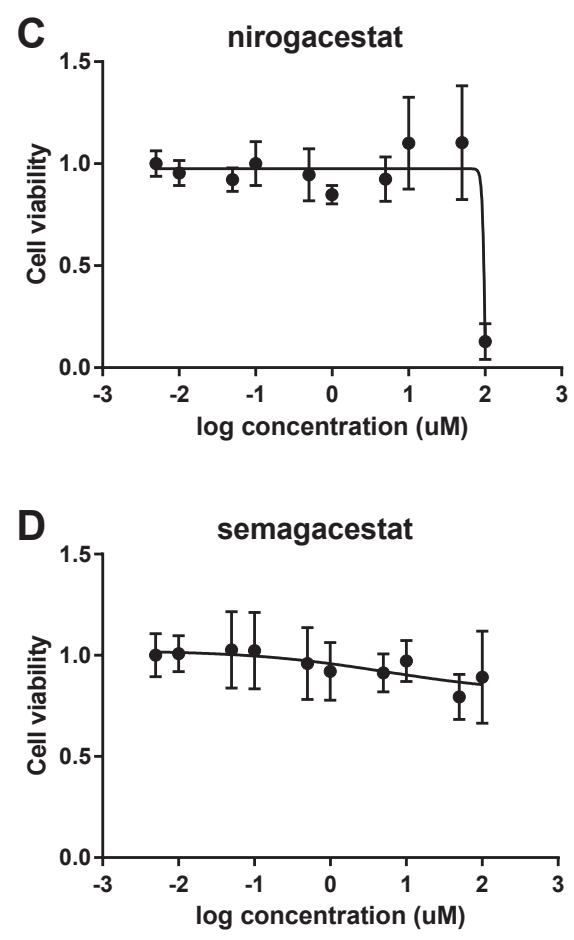
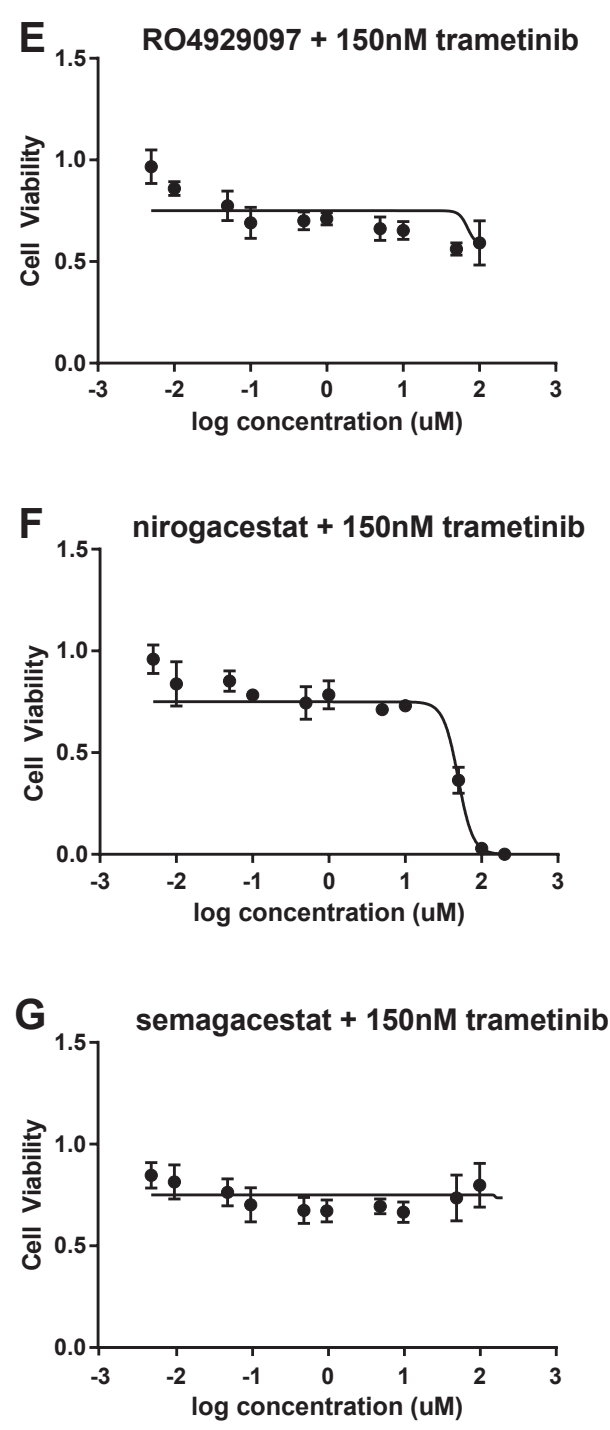
bioRxiv preprint doi: https://doi org/10.1101/622522; this version posted April 29, 2019. The copyright holder for this preprint (which was not certified by peer review) is the author/funder, who has granted bioRxiv a license to display the preprint in perpetuity. It is made available under aCC-BY-NC-ND 4.0 International license.

Figure 3
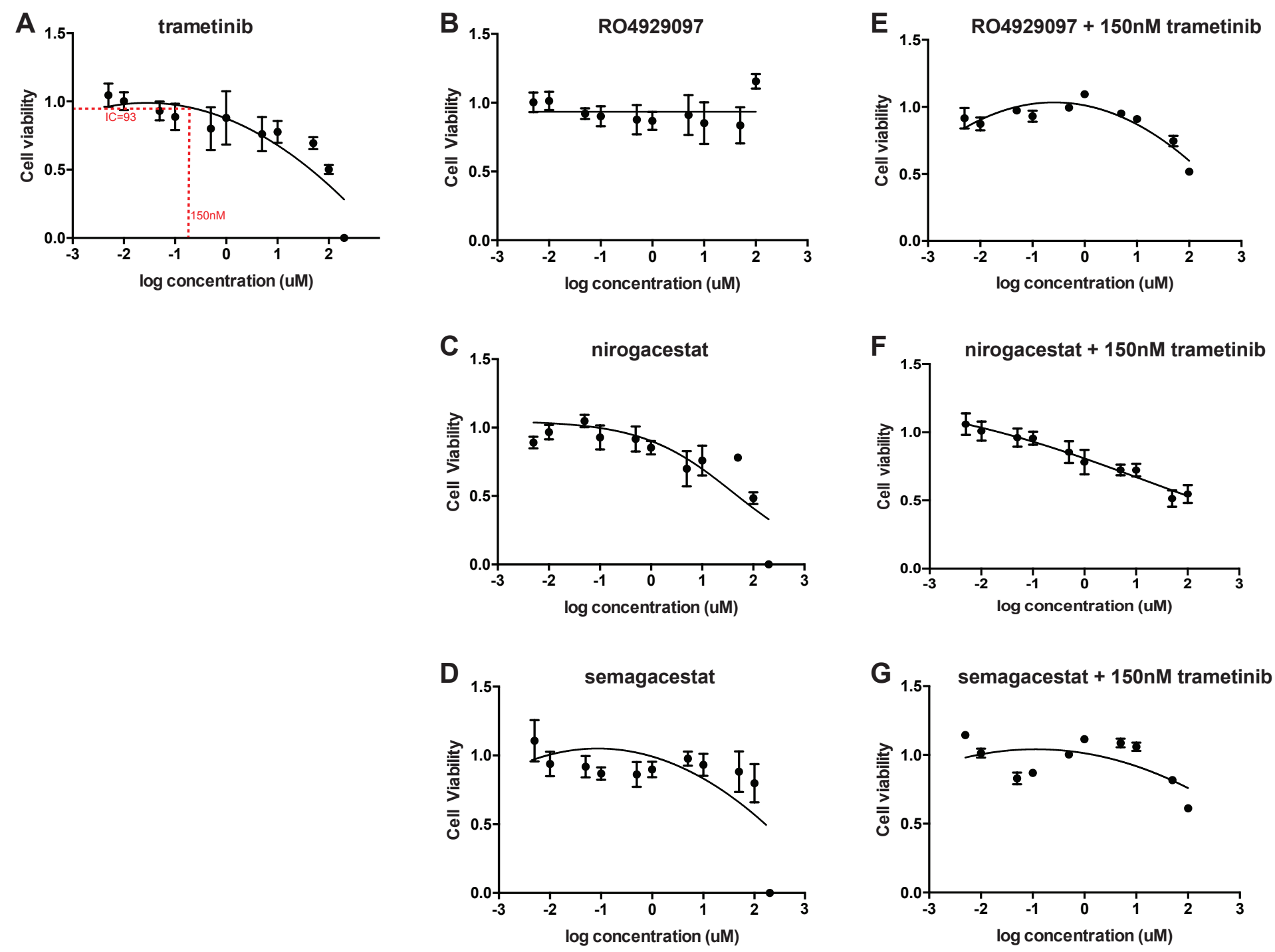
bioRxiv preprint doi: https://doi. org/10.1101/622522; this version posted April 29,2019 . The copyright holder for this preprint (which was not certified by peer review) is the author/funder, who has granted bioRxiv a license to display the preprint in perpetuity. It is made available under aCC-BY-NC-ND 4.0 International license.

Figure 4
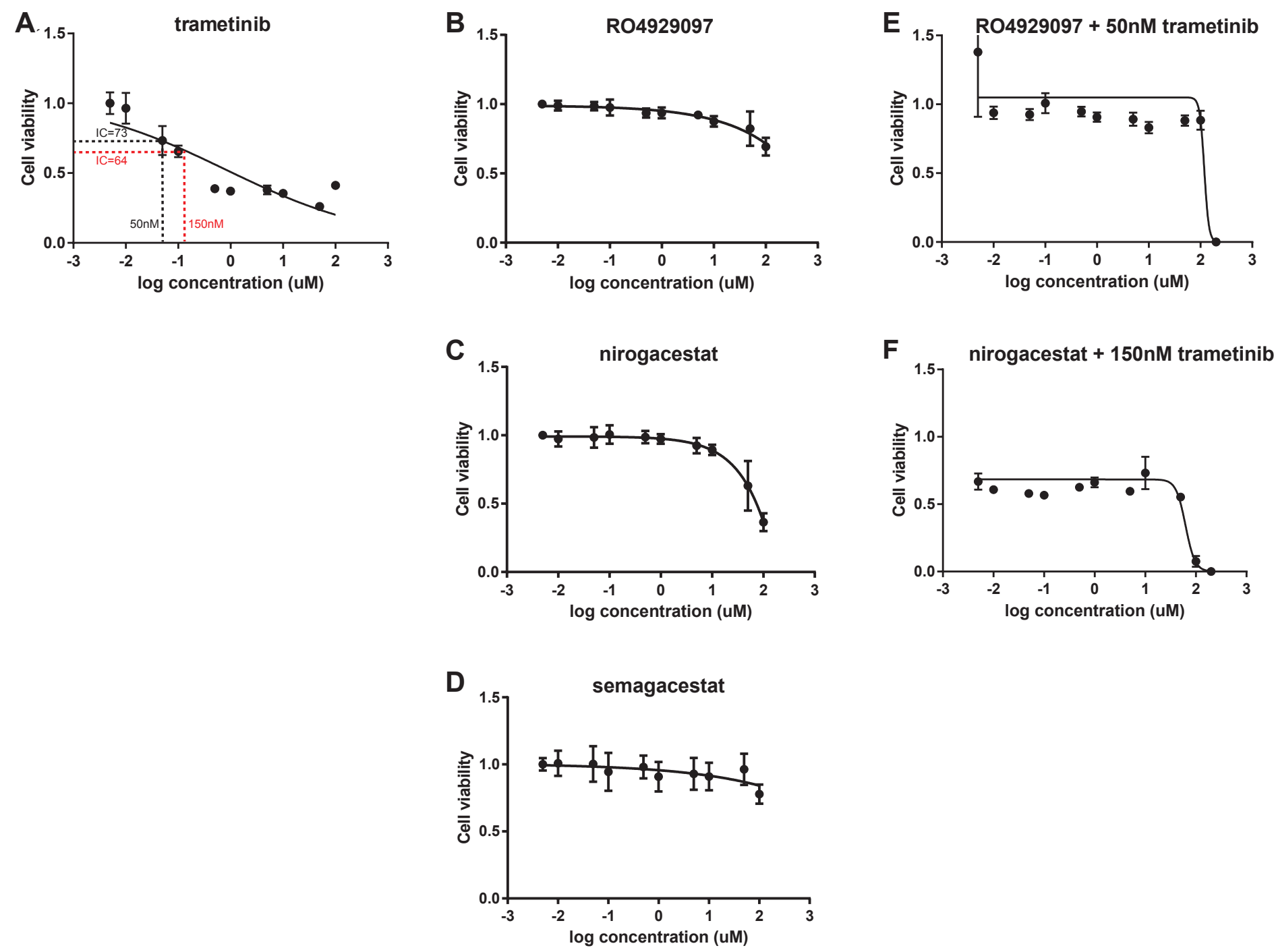
bioRxiv preprint doi: https://doi org/10.1101/622522; this version posted April 29,2019 . The copyright holder for this preprint (which was not certified by peer review) is the author/funder, who has granted bioRxiv a license to display the preprint in perpetuity. It is made available under aCC-BY-NC-ND 4.0 International license.

\section{Figure 5}
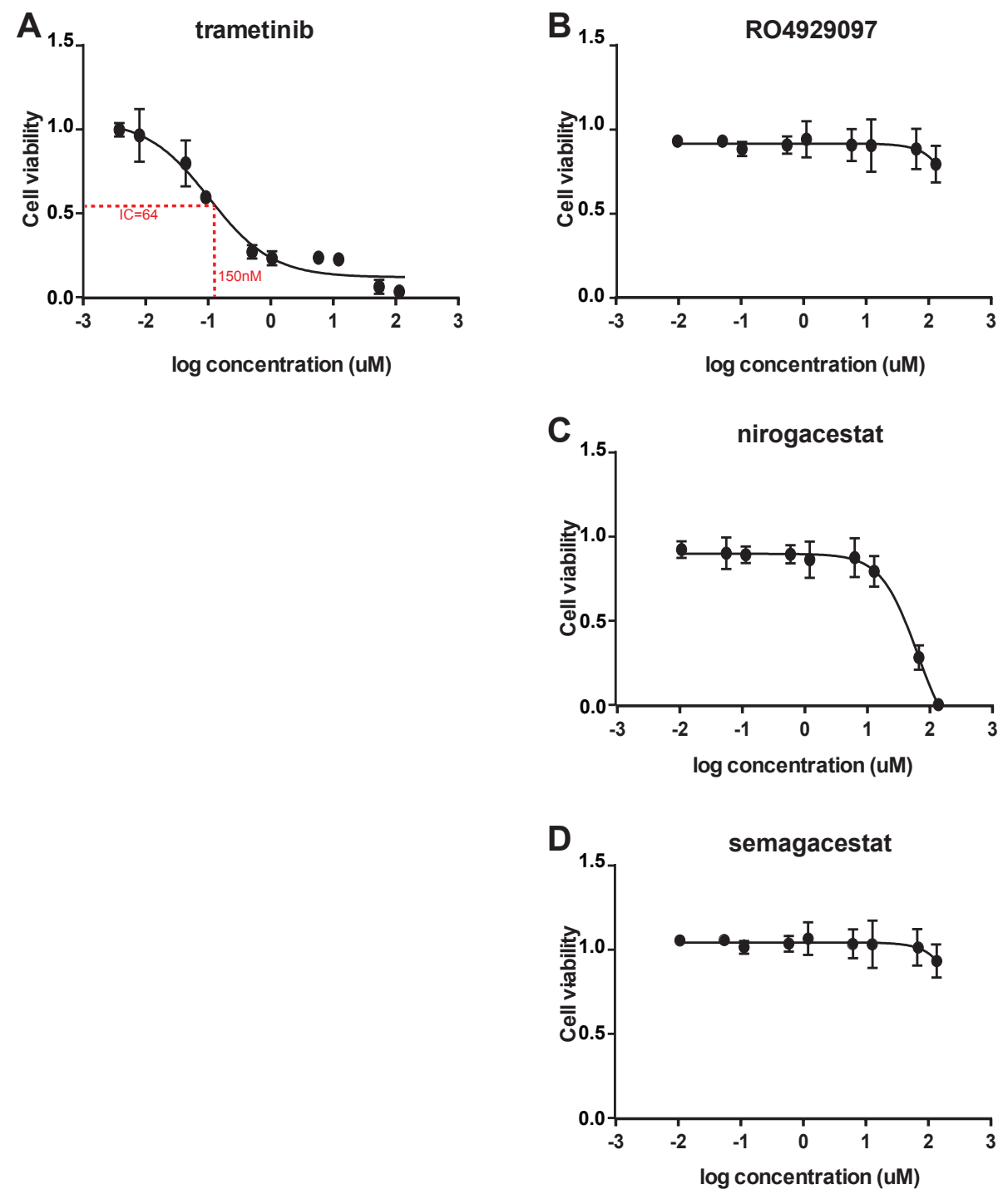
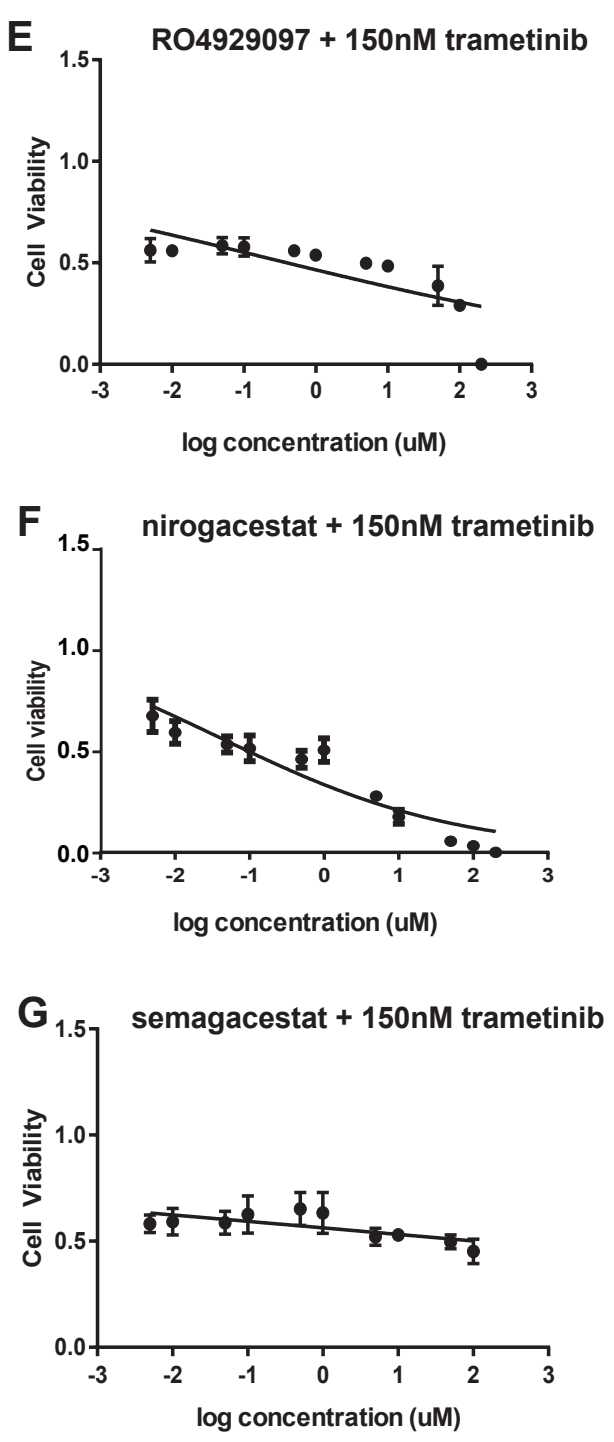
Table 1. Cell lines used for this study

\begin{tabular}{|c|c|c|c|}
\hline Name & Origin & Genetic features & Histology \\
\hline RD & 7 year old female & $\begin{array}{c}\text { MYC amplification, NRAS Q61H mutation, TP53 } \\
\text { mutation }\end{array}$ & eRMS \\
\hline Rh30 & 16 year old male & $\begin{array}{c}\mathrm{t}(2 ; 13), \mathrm{PAX} 3: \mathrm{FOXO1}, \mathrm{TP53} \text { mutation, } \\
\text { amplification of } 12 \mathrm{q} 13-15 \text { region including } \\
\text { CDK4 }\end{array}$ & aRMS \\
\hline CF-1 & 5 year old male & $\mathrm{t}(2 ; 13)$, PAX3:FOXO1 & aRMS \\
\hline CW9019 & human & $\mathrm{t}(2 ; 13)$, PAX7:FOXO1, TP53 mutation & aRMS \\
\hline SCA-1 & mouse & KRAS, p16p19 null & $\begin{array}{l}\text { NMS (non-myogenic } \\
\text { sarcoma) }\end{array}$ \\
\hline
\end{tabular}

Table 2. Drugs used for this study

\begin{tabular}{|c|c|c|c|c|c|c|}
\hline $\begin{array}{l}\text { Generic } \\
\text { name }\end{array}$ & Brand name & Target & $\begin{array}{c}\text { Vendor, Cat \#, } \\
\text { Lot \# }\end{array}$ & \multicolumn{3}{|c|}{ Trial status } \\
\hline LY450139 & semagacestat & $\begin{array}{c}\gamma \text {-secretase } \\
(A \beta 42, A \beta 40, \\
A \beta 38), \text { Notch }\end{array}$ & $\begin{array}{c}\text { Selleckchem } \\
\text { S1594, } \\
\text { S159402 }\end{array}$ & $\begin{array}{l}\text { Alzheimer's } \\
\text { disease }\end{array}$ & $\mathrm{Ph} 3$ & Completed \\
\hline PF03084014 & nirogacestat & $\gamma$-secretase & $\begin{array}{c}\text { Selleckchem } \\
\text { S1575, } \\
\text { S157504 }\end{array}$ & $\begin{array}{c}\text { Desmoid } \\
\text { tumors, } \\
\text { Fibromatosis }\end{array}$ & $\mathrm{Ph} 2$ & Active \\
\hline RO4929097 & & $\begin{array}{c}\gamma \text {-secretase } \\
\text { (A } \beta 40) \\
\text { Notch }\end{array}$ & $\begin{array}{c}\text { Selleckchem } \\
\text { S8018, } \\
\text { S801801 }\end{array}$ & $\begin{array}{l}\text { No active or } \\
\text { recruiting trials }\end{array}$ & & \\
\hline trametinib & mekinist & MEK1/2 & $\begin{array}{l}\text { Selleckchem } \\
\text { S2673, } \\
\text { S267308 }\end{array}$ & $\begin{array}{l}\text { Metastatic } \\
\text { melanoma }\end{array}$ & $\begin{array}{c}\text { FDA } \\
\text { approved }\end{array}$ & May 2013 \\
\hline
\end{tabular}

